\title{
III論文＼cjkstart封圧下の圧縮試験で得られた砂岩の変形・破壊特性*
}

一 砂岩の変形・強度特性と組織に関する基礎的研究（第 2 報）-

萩 野 克 彦 ${ }^{1}$ 中 村 章 $^{2}$ 石 島 洋 二 ${ }^{3}$

\author{
Mechanical Properties and Behavior of Sandstones under \\ Triaxial Compression \\ - Fundamental study on mechanical properties and fabric of sandstones ( 2 nd Report) - \\ by Katsuhiko HAGINO ${ }^{1}$, Akira NAKAMURA ${ }^{2}$ and Yoji ISHIJIMA ${ }^{2}$ \\ 1. Graduate Student, Hokkaido University \\ 2. Faculty of Engineering, Hokkaido University, Kita - ku, Sapporo 060
}

\begin{abstract}
Triaxial compression tests on Ishikari sandstones, using a stiff servo-controlled machine, have revealed the following:

1. The peak strength criterion is expressed as a bent line in the $\left(\sigma_{1}-\sigma_{3}\right)$-space. The shear angles predicted based on the criterion coincide with the measured ones, and their values are constant for confining pressures higher than the pressure corresponding to the bending point.

2. When the difference between the maximum and minimum P-wave velocities is more than $4 \%$, the preferred orientation of the shear plane coincides with the direction of minimum velocity. On the contrary, when this difference is less than $4 \%$, the shear plane is randomly oriented. A yielding zone develops around the shear plane, whose width become narrower with the degree of brittleness. Inside this zone the material readily disintegrates when dipped into water, due to loss of cohesion.

3 . Single shear-type fracturing is dominant for the specimen whose P-wave velocity transmitted perpendicular to the loading axis shows anisotropy; and cross-shear type for specimens whose velocity profiling reveals isotropic condition.

KEY WORDS : Triaxial Compression Test, Peak Strength Criterion, Fracture Mode, Fracture Orientation, Brittle-Ductile Transition, Cataclastic Flow
\end{abstract}

\section{1. 紸}

本研究の目的は, 石狩夾炭層砂岩を中心とする砂岩の組織が変 形・破壊特性とどのように関わっているかを明らかにすることに ある。第 1 報（萩野ら，1996 a ）では, P 波速度の計測と顕微鏡 観察から岩石の組織を調べるとともに地質作用との関連性につい て検討し, 孔隙率の減少や層構造の形成が過去に履歴したかぶり 圧の大きさに支配されていること, 地層が激しい造構運動を受け ると, 層理に平行な面内の組織にも褶曲軸と平行に配向した開口 き裂が発達し組織の異方性をもたらすことなどを明らかにした。

本報では，まず，封圧下の圧縮試験で得られる砂岩の力学的性 質についてまとめ，本供試岩石の組織の異方性が，強度特性には ほとんど影響しないにもかかわらず，破壊モードや破断方位には 強く影響することを示す。次に, P 波速度, 鏡下の観察, 浸水崩

* 1996 年 1 月 5 日受付 5 月 7 日受理

1. 学生会員 北海道大学大学院

2. 正会員 工博 北海道大学助手 工学部資源開発工学科

3. 正会員 工博 北海道大学教授 工学部資源開発工学科

〔著者連絡先〕 FAX 011-716-6175（北大・資源）

キーワード: 三軸圧縮試験, 破壊基準, 破壞モード, 破断方位, 脆性一延性遷移, 砕屑性流動
壊試験の諸結果を基に，岩石の破断後の損傷状態を明らかにし， 組織の異方性は脆性・延性のいずれの場合にも失われないこと, 脆性から延性への遷移は微小き裂の密集した領域の拡大を伴うこ とを示す。

\section{2. 供試岩石および試験方法}

供試岩石の種類および供試体の整形方法や寸法については第 1 報で述べたとおりである。試験に際しては, 供試体の上下端に同 径のエンドピースを装着し，また，側面には横方向変位計測用の 一対のアタッチメントを $\mathrm{P}$ 波速度の最も遅い方向に向けて接着 した。その後, 供試体への封圧媒体（潤滑油 80 番）の浸透を防 止するため, アタッチメント頭部を除く供試体全側面をシリコン ゴムで被覆した。

供試体には, 最大荷重 160 tonf, 応答周波数 $200 \mathrm{~Hz}$, 反力枠 のフレーム剛性 600 tonf/mm のサーボ制御システムに基づく両 振り加振機 (東京衡機製造所製) で軸応力を負荷した。このサー ボ制御システムのフィードバック信号には, 供試体の軸方向およ び横方向に取り付けた変位変換器 (応答周波数は, 軸方向が 280 $\mathrm{Hz}$, 横方向が $310 \mathrm{~Hz}$ ）の出力を用いた。荷重変換器は変位変換 器と同様に圧力容器内に設置し, 出力はパソコンに取り込み記録 
した。データサンプリング間隔の最高分解能は $20 \mu \mathrm{sec}$ である。 供試体は，設定封圧まで静水圧縮した後， $2.0 \times 10^{-5} / \mathrm{sec}$ の 軸ひずみ速度あるいは横ひずみ速度で軸圧を負荷し, 脆性の場合 は残留強度点に至った時点で, 延性の場合は軸ひずみが $5 \%$ あ るいは $10 \%$ に達した時点で, それぞれ除荷した。なお, 本文で は差応力〜軸ひずみ線図において応力低下がある場合を脆性，な い場合を延性と呼ぶ。

\section{3. 封圧下の圧縮試験結果}

\section{$3 \cdot 1$ 強度特性}

図 1 は供試体軸と層理のなす角度が $\alpha=90^{\circ}$ の赤平砂岩につい て, 破壊強度ならびに残留強度と封圧の関係を最大圧縮応力（軸 応力 $\sigma_{1}$ ) 一最小圧縮応力 (封圧 $\sigma_{3}$ ) 座標に示したものである。試 験条件として先に述べた 2 種の制御方法および 2 種の縦横比を採 用した。

封圧が大きい領域の破壊強度は, 図に示す直線のまわりに集中 しており, 破壊限界線のよい近似を与えるこの直線を次式で表す ことにする。

$$
\begin{gathered}
\sigma_{1}=A_{2} \sigma_{3}+\left(A_{1}-A_{2}\right) \sigma_{3}^{*}+C_{0} \\
A_{1}, A_{2}, \sigma_{3}^{*}, C_{0}: \text { 正の定数 }
\end{gathered}
$$

しかし, 封圧が小さくなるにつれて, 破壊強度の実測值と(1) 式による予測值のずれは次第に広がる。そこで，低封圧領域では 破壊限界線として (1)式とは傾きの異なる直線

$$
\sigma_{1}=A_{1} \sigma_{3}+C_{0}
$$

をあてはめる。このように, 破壊限界線が傾きの異なる 2 直線で 表現される場合の破壊基準を双線形破壊基準と呼ぶ（中村·石島， 1987 ; 1988)。

2 直線の交点は

$$
\sigma_{3}=\sigma_{3}^{*}
$$

で与えられるが, $\sigma_{3} \leqq \sigma_{3}{ }^{*}, \sigma_{3} \geqq \sigma_{3} *$ で定義される領域を, 以 下では領域 I, II と呼ぶことにする。 $\sigma_{3}{ }^{*}$ は岩石の採取深度と関 わっているが，このことについては第 3 報（萩野ら，1996 b ）で

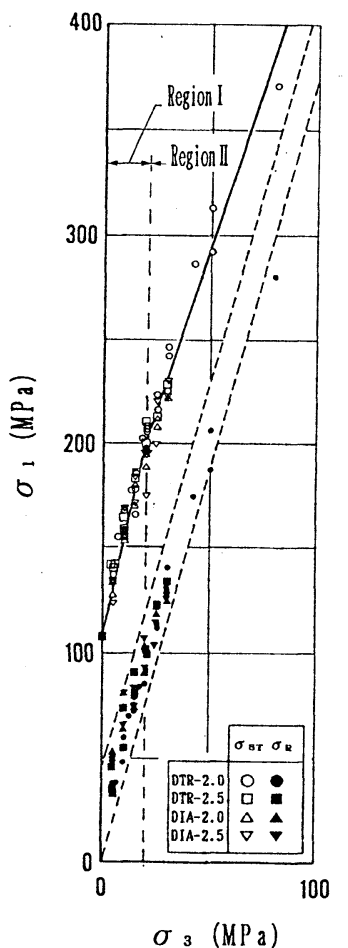

図 1

破壊強度と残留強度の $\sigma_{1}-\sigma_{3}$ 座標 表示。図中には破壊限界線として 傾きの異なる 2 直線 (実線) と残 留強度の存在範囲を示す 2 本の直 線（破線）が示されている(赤平 砂岩, $\alpha=90^{\circ}$, 試料数 60 個)。 $\sigma_{s t}$ : 破壊強度, $\sigma_{R}$ : 残留強度, DTR：軸ひずみ速度制御，DIA： 横ひずみ速度制御， 2.0 および 2.5 は縦横比。

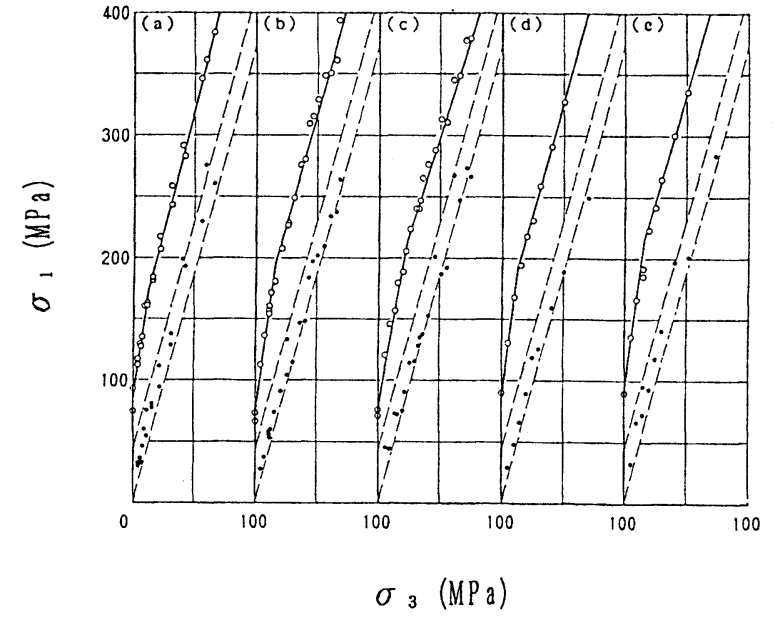

図 2 破壊強度および残留強度に及ぼす供試体軸と層理のなす 角度 $\alpha$ の影響（寒沢砂岩）。 0 : 破壊強度, 0 : 残留強度。 (a) $\alpha=90^{\circ}$ (試料数 21 個)，（b） $\alpha=0^{\circ}$ で供試体軸が $\mathrm{L}$ 方向に一致 ( 22 個 $),(\mathrm{c}) \alpha=0^{\circ}$ で供試体軸が $\mathrm{H}$ 方向に一 致 (21 個), (d) $\alpha=30^{\circ}$ (10 個)，(e) $\alpha=60^{\circ}$ (11 個)。 図中の実線と破線は図 1 と同じ意味をもっている。

述べることにする。

測定結果に合う 2 直線を規定する 3 つの諸定数 $A_{1}, A_{2}, \sigma_{3}{ }^{*}$ は次の方法で決める。なお, 定数 $C_{0}$ は (2) 式より封圧が大気圧 下の強度, すなわち, 単軸圧縮強度に等しいので, この測定值を 用いる(第 1 報の $4 \cdot 1 \cdot 1$ 参照)。

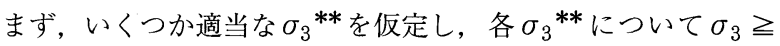
$\sigma_{3}{ }^{* *}$ と $\sigma_{3} \leqq \sigma_{3} * *$ の 2 つ領域で最小 2 乗法により個別に直線 を決め, これから 3 つの諸定数 $A_{1}, A_{2}, \sigma_{3}$ *を定める。次に, 2 つの領域ごとに直線と測点の残差平方和を計算し両者の和を求 め, この和が最小になる諸定数を正解とする。いずれの領域につ いても相関係数は $95 \%$ を超えており, 双線形破壊基準の適合性 は高い。また, 測定結果は上記の 4 通りの試験条件下で得たもの であるので, これらの条件の差異は破壊強度に影響していないと 判断される。

4 通りの試験条件下で得た残留強度点は, 若干分散してはいる ものの, 図中の 2 本の平行な破線を境界とする狭い帯状領域内に 収まっており, 残留強度も採用した試験条件に依存していないこ とがわかる。図中の破線は,

$$
\sigma_{1}=3.7 \sigma_{3}, \quad \sigma_{1}=3.7 \sigma_{3}+43(\mathrm{MPa})
$$

で表されるが，これは筆者らが主に古第三系の砂岩を用いて従来 実施した封圧下の圧縮試験で得た残留強度の分布範囲の境界を与 えるものであり (中村, 1978), 本試験結果とも一致している。 なお, 脆性・延性や残留強度の定義からいえば, この帯状領域は 脆性一延性遷移領域を表している。

図 2 は寒沢砂岩における強度一封圧の関係を供試体軸と層理の なす角度 $\alpha$ 別に示したものである。図には双線形性を仮定した破 壊強度の限界線, ならびに(4)式による残留強度の分布範囲が記 されている。

$\alpha$ 別に求めた破壊強度の限界線を定める定数の值は互いに似て おり，したがって，破壊強度は等方的であるといえる。また，残 留強度も $\alpha$ の值によらず(4)式を境界とする領域に収まっており, やはり等方的といえる。

\section{$3 \cdot 2$ 体積ひずみ挙動}

図 3(a), (b)は, 最大 $80 \mathrm{MPa}$ までの封圧下の圧縮試験で脆性 破壊した赤平砂岩と寒沢砂岩の差応力〜体積ひずみ線図である。 いずれもダイラタンシーの発生を示す線図の反転が見られる。反 


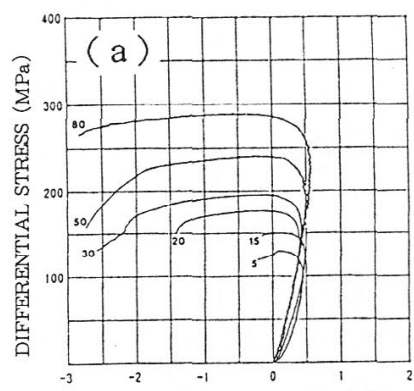

VOLUMETRIC STRAIN (\%)

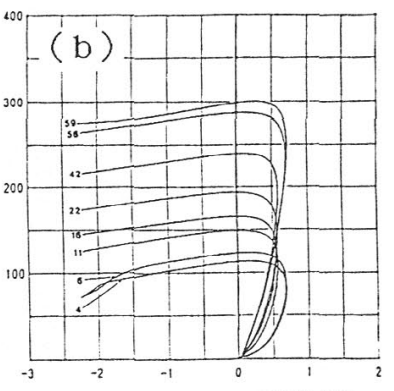

VOLUMETRIC STRAIN $(\%)$

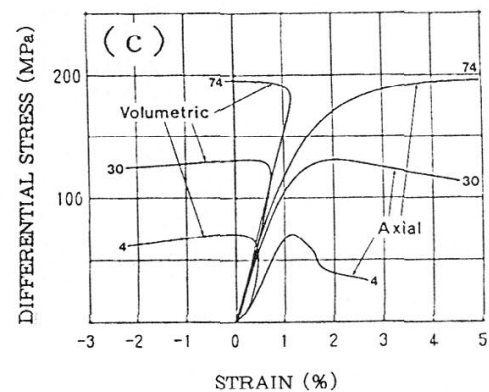

図3 差応力〜体積ひずみ線図（軸ひずみ速度制御， $\alpha=90^{\circ}$ )。 (a) 赤平砂岩, (b) 寒沢砂岩, (c)太平洋砂岩。図中の数值 は設定封压 $(\mathrm{MPa})$ 。

転時の軸応力は破壊强度よりは低いが，封圧とともに増加してい る。

線図の形には領域 I , II で次のような差異が見られる。領域 II では, 線図が反転するまでは封圧の大きさに係わりなくほぼ直線 的である。これに対し，領域Iでは，圧縮側に暿らんでおり，封 圧が小さいほどこの傾向が顕著である。

なお，露天から採取した寒沢砂岩の場合，4〜6 MPa の低封圧 下における線図の立ち上がり部は，圧縮側へ著しく澎らんでおり， 僅かの差応力を負荷するだけで緩んだ構造が急激に締まっていく ことを示している。地下深部（深度 $800 \mathrm{~m}$ ) 功採取した赤平砂 岩ではこのような挙動は見られないので，この特徴は粒界の緩み に起因していると考えられる（第 1 報， $3 \cdot 3$ 参照）。

太平洋砂岩は, 図(c)のように, 封圧 $74 \mathrm{MPa} の$ ときに延性を 示した。この場合, 軸ひずみが $5 \%$ に達した時点でも体積ひず みは０に近く，供試体は膨張しにくくなっている。これは，高い 封圧が微小な破壊き裂の発生や伸展を抑制するためと考えられる。

\section{$3 \cdot 3$ 破断角および破断面の様相}

図 4 は, 脆性破壊した赤平砂岩の破断角と封圧の関係を示した もので，破断角は試験条件によらず，封圧とともに徐々に増加し，

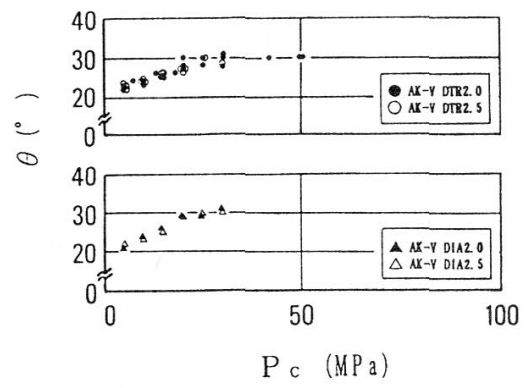

図 4 赤平砂岩の破断角 $\theta$ と封压 $P_{c}$ の関係。供試体と層理のな 角度 $\alpha$ は90。DTR：軸ひずみ速度制御，DIA：横ひず み速度制御，2.0 および 2.5 は縦横比を示す。
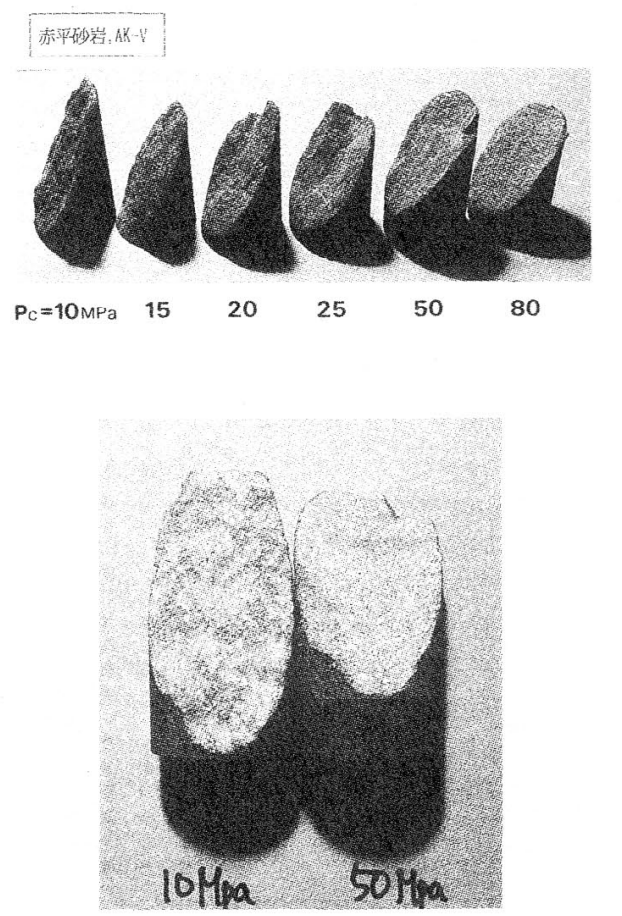

図 5 破断面の様相 (赤平砂岩, $\alpha=90^{\circ}$ )。 $P_{C}$ は設定封圧值を 示す。

ある大きさの封圧（今の場合，20 MPa）以上ではほほ一定となっ ている（破断角の定義については，第 1 報の $2 \cdot 2$ 参照）。

破壊限界線が決まれば，所与の封圧に対して破壊条件を満たす 面の向きとして破断角が定まるが，このようにして得られる角度 を理論的な破断角と呼ぶことにする。領域 IIでは，破断角の実測 值は一定值を取り，しかもこの理論的な破断角に一致している。 領域 I では，破断角の実測值は封圧とともに若干変化しているが, 平均值は理論的な破断角にほぼ等しい。このように破断角と封圧 の関係の観点からも，双線形性の破壊限界線が合理的であること がわかる。

図 5 は破断面の様相を示したものである。封圧が $20 \mathrm{MPa}$ 以下 の場合，破断面は円凸が著しく，表面の多くは擦過されて粉状化 しているが，破断面にはまた斑状に分布する引張型の破面も見ら れる(図 5 下段左側参照)。この引張型の破面の特徴は供試体軸 に対してほぼ平行になっていることである。封圧が $20 \mathrm{MPa}$ 以上 の場合，破断面はより平面的となり，擦過部が全面に広がって， 引張型の破面は消失している(図 5 下段右側参照)。

破断面の状態には，供試体軸と層理のなす角度 $\alpha$ の影響が僅か ながら認められた。 $\alpha$ が $30^{\circ}$ の破断面は，他の角度の下で得られ た破断面に比べより平坦であり，多くの場合，層構造に沿って破 断が生じていた。この傾向は層構造が明瞭な白浜砂岩や太平洋砂 岩で顕著であった。

\section{$3 \cdot 4$ 破壊モ一ド}

岩石の破壊形態に関しては，封圧の増大に伴い破壊挙動が脆性 から延性へと変化するのに対応して，図6に示すように，縦割れ， 単一せん断, 二重せん断・共役せん断, 多重せん断, 一様流動の 破壊モードが出現するといわれている（Griggs \& Handin, 1960 ; 茂木，1974)。一般に，砂岩の破壊モードは，低封圧下に扮いて は単一せん断型が卓越するが，本供試岩石の場合には，このほか に，もう一つ別の型がしばしば見られた。この型は，たいてい互 いに鋭角に交わる複数の破面を持っており，二重せん断型や共役 

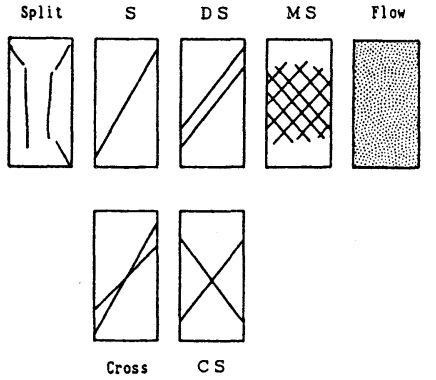

図 6 岩石の封圧下の圧縮試験で現れる破壊モード。Split：縦 割れ，S：単一せん断，DS：二重せん断，CS：共役せん 断, MS : 多重せん断, Flow : 一梯流動, Cross : 交差せ ん断。一般に, 封圧が増大するにつれて現れる破壊モ一 ドは右側へ移るといわれている。

せん断型の破壊モードと明瞭に区別できるので, 交差せん断と名 付け，破壊モードの新たな一形態に加えることにした。

なお，Donath et al.（1971）によれば，脆性破壊時に見られ る破壊モードは「brittle faulting」と「ductile faulting」の 2 つに分類される。本供試岩石の場合，脆性破壊時の破壊モードは, 単一せん断と交差せん断で占められ，明瞭な破断面の形成を伴う 「brittle faulting」のみが見られた。

太平洋砂岩は，供試体軸と層理のなす角度 $\alpha$ にかかわらず，75 $\mathrm{MPa}$ 程度の封圧下で延性を示した。これらの供試体は, すべて 一様流動し, 明瞭な破断面の形成は認められなかった。

脆性破壊時の破壊モードには $\alpha$ の影響が認められた。 $\alpha=$ $90^{\circ}$ (供試体軸が層理に垂直) の場合, 石狩夾炭層砂岩の破壊モ一 ドは，ほとんどが単一せん断型であった。これに対し，太平洋砂 岩および白浜砂岩では，単一せん断型が全体に占める割合は 30 \% 程度に留まり, 残りは交差せん断型で占められた。 $\alpha=0^{\circ}$ （供試体軸が層理に平行）の場合には，すべての岩種に共通して， 単一せん断型が圧倒的に多く現れた。供試体軸と層理が斜交した $\alpha=30^{\circ}$ の場合には, 単一せん断型だけが現れた。 $\alpha=60^{\circ}$ の場 合には, 交差せん断型が卓越し, 単一せん断型の占める割合は約 $30 \%$ に留まった。

単一せん断型の破壊モードの出現率 Rs（％）を，100×（単一 せん断型の破壊モードが現れた供試体数)/(全供試体数)，で定義 する。図 7 は, $R_{s}$ と $\mathrm{P}$ 波速度の異方性の程度 $V_{p \text {-aniso }}$ の間に成 立する関係を示したもので（ $V_{p \text {-aniso }}$ の定義については，第 1 報 の 3 ・ 1 参照)， $\mathrm{P}$ 波速度の異方性が強いほど，単一せん断型の 破壊モードの出現する率が高くなっている。また，P 波速度の異

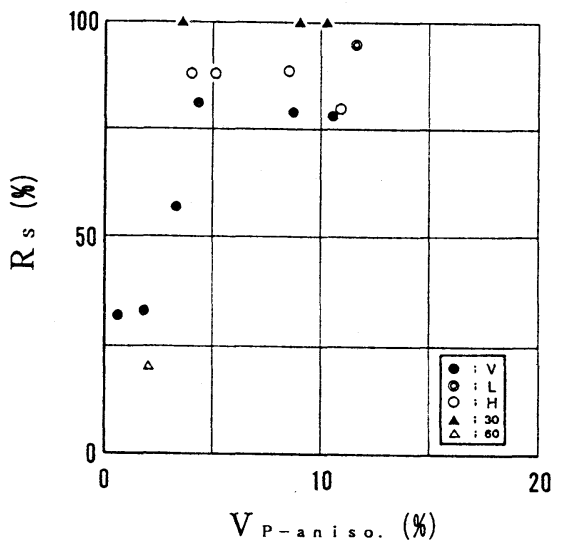

図 7 径方向 $\mathrm{P}$ 波速度の異方性の程度 $V_{p \text {-aniso }}$ と破壊モードの 関係。縦軸は単一せん断型の破壊モードの占める割合 $R_{\mathrm{s}}$ を示す。 : $\alpha=90^{\circ}$, (0): $\alpha=0^{\circ}$ (供試体軸が L 方向 に一致), $\bigcirc: \alpha=0^{\circ}$ (供試体軸が $\mathrm{H}$ 方向に一致), $\boldsymbol{\Delta}$ $\alpha=30^{\circ}, \Delta: \alpha=60^{\circ}$

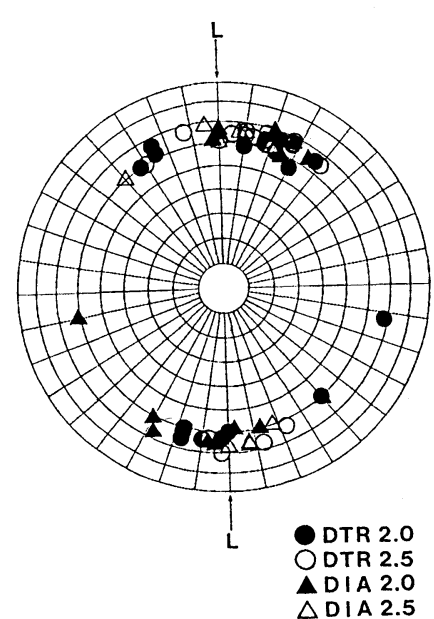

図 8 破断方位に及ほすす制御方法・縦横比の影響（赤平砂岩, $\left.\alpha=90^{\circ}\right)$ 。破断方位は供試体軸を極とするシュミットネッ トにプロットされている。図 11,12 も同様。DTR : 軸 ひずみ速度制御, DIA：横ひずみ速度制御, $2.0 \cdot 2.5$ は縦 横比を示す。矢印は径方向 P 波速度の最も遅い方向（い まの場合 L方向）を示す。

方性が同程度の場合は, $\alpha=90^{\circ}, 0^{\circ}, 30^{\circ}$ の順に単一世ん断型 の破壊モードの出現率が高くなっている。

\section{$3 \cdot 5$ 破断方位}

$3 \cdot 5 \cdot 1$ 破断方位に及ぼす制御方法と綐横比の影響 破 断方位が制御方法と縦横比の影響を受けるか否かを見るために （破断方位の定義については，第 1 報の 2 - 2 参照)，赤平砂岩に ついて制御方法と縦横比の 4 通りの組合せ別に，破断方位を供試 体軸を極としたシュミットネット上にプロットしてみた。その結 果を示した図 8 からわかるように, 各組合せとも分布の状態は互 いに似ており，破断方位は採用した試験条件には依存していない と判断される。

$3 \cdot 5 \cdot 2$ 破断方位の集中の程度 破断方位の傾向を捉え るために，2つの量を導入する。第 1 は破断方位の卓越する向き $\phi_{\text {rep }}\left(^{\circ}\right)$ で, $0^{\circ}$ から $180^{\circ}$ まで $1^{\circ}$ 間隔でその方向に関する破断 方位の変動係数を求め，この值が最小になる方向と定義する。第 2 は破断方位の集中の程度 $\psi_{\text {cons }}$ で，次式によって定義する。

$$
\begin{aligned}
& \left.\phi_{\text {cons }}=100 \times\left[1-\left(d_{1} / d_{2}\right)\right] （ \%\right) \\
& d_{1}=\phi_{\text {rep }} \text { に関する変動係数 } \\
& d_{2}=\text { 破断方位が均等に分散するとした場合の変動係数 }
\end{aligned}
$$

上記の 2 つの量と $\mathrm{P}$ 波速度の分布特性の間の関係について調 べてみる。まず, 方位 $\psi_{\mathrm{rep}}$ と径方向の $\mathrm{P}$ 波の最も遅い方向との

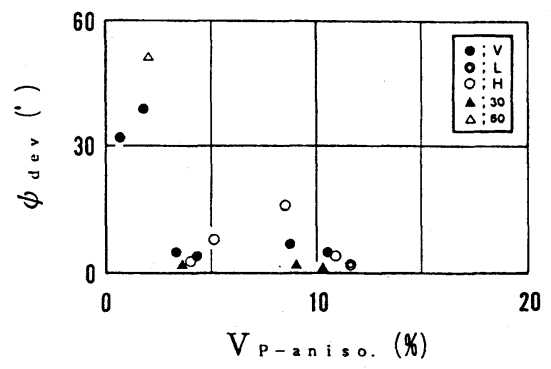

図 92 つの量 : 径方向 $\mathrm{P}$ 波速度の異方性の程度 $V_{p \text {-aniso およ }}$ び最も遅い速度の向きと卓越する破断方位との偏差 $\phi_{\mathrm{dev}}$ び最も遅い速度の向きと卓越する破断方位との偏差 $\phi_{\mathrm{dev}}$,
の間に成立する関係。: $\alpha=90^{\circ}, 0$ ( $: \alpha=0^{\circ}$ (供試 体軸が L 方向に一致), $\bigcirc: \alpha=0^{\circ}$ (供試体軸が $\mathrm{H}$ 方向 に一致), $\Delta: \alpha=30^{\circ}, \Delta: \alpha=60^{\circ}$ 。 


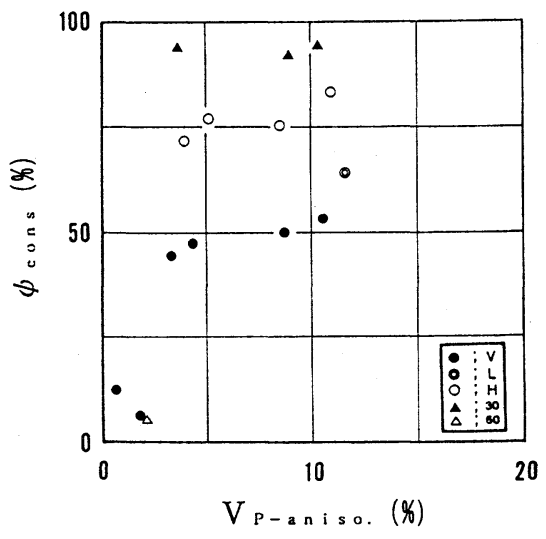

図 10 径方向 $\mathrm{P}$ 波速度の異方性の程度 $V_{p \text {-aniso }}$ と破断方位の集 中度 $\phi_{\text {cons }}$ の関係。 $: \alpha=90^{\circ}, \stackrel{p}{\mathrm{O}}: \alpha=0^{\circ}$ (供試体 軸が L 方向に一致), $\bigcirc: \alpha=0^{\circ}$ (供試体軸が $\mathrm{H}$ 方向に 一致), $\Delta: \alpha=30^{\circ}, \Delta: \alpha=60^{\circ}$

偏差 $\psi_{\mathrm{dev}}\left(^{\circ}\right)$ と, 径方向の $\mathrm{P}$ 波速度の異方性の程度 $V_{p \text {-aniso }}$ の間に成立する関係を図 9 に示す。図から，P波の異方性の程度 が $4 \%$ 以上になると，偏差 $\phi_{\mathrm{dev}}$ はほほ $0^{\circ} に な り ， \mathrm{P}$ 波速度にわ ずかな異方性があるだけで, 破断方位は $\mathrm{P}$ 波速度が最小になる 方向に一致することがわかる。

$3 \cdot 5 \cdot 3$ 破断方位と岩石組織および地質作用の関係 図 10 は, 2 つの量, 破断方位の集中の程度 $\phi_{\text {cons }}$ と径方向の $\mathrm{P}$ 波速 度の異方性の程度 $V_{p \text {-aniso }}$ の関係を示したもので, 以下の 3 点 が注目される。

1） $\mathrm{P}$ 波速度の分布が等方的であれば破断方位は分散するが, $4 \%$ 以上の異方性があると破断方位の集中度が高くなる。

2）両者の関係は供試体軸と層理のなす角度 $\alpha$ の影響を若干受 け，P波速度の異方性が同程度の場合は，角度 $\alpha$ が $90^{\circ}, 0^{\circ}$, $30^{\circ}$ の順に集中の程度が高くなっている。

3）図 10 と図 7 は同一の傾向を示しているので, 破断方位が 集中するほど，単一せん断型の破壊モードの出現率が高くなると いえる。また，破断方位と破壊モードに対する角度 $\alpha$ の影響の仕 方も同じである(上記 2$) と 3 \cdot 4$ 参照)。

図 11 は, 知見 1)の一例を示したもので, 供試体軸が層理と斜 交する $\alpha=30^{\circ}$ および $60^{\circ}$ の場合の破断方位の分布図である。 $\alpha$ $=30^{\circ}$ の場合, 図(a)(b)(c)に示すように, 寒沢砂岩, 太平洋砂 岩, 白浜砂岩のいずれにおいても, 破断方位は $\mathrm{P}$ 波速度の最も 遅い層理の傾斜方向へ集中している。角度が $\alpha=60^{\circ}$ の場合は, 図(d)に示すように, 径方向の $\mathrm{P}$ 波速度が等方的なことを反映し て(第 1 報の $3 \cdot 1$ 参照)，破断方位は分散している。

角度 $\alpha$ が $90^{\circ}$ （供試体軸が層理に垂直）の場合の破断方位の分 布状況を図 12 に示す。この図から，太平洋砂岩および白浜砂岩 の破断方位は完全に分散していることがわかる。一方，石狩夾炭 層砂岩の場合には，いずれの供試岩石についても，破断方位は L 方向に集中している（なお，同じ図を第 1 報の図 14 に示した）。

$3 \cdot 5 \cdot 4$ 破断方位を支配する機構 周知のように, ダイ ラタンシーは供試体軸に平行な微小なき裂の発生と伸展によって もたらされ，高封圧下でその発生が抑制されるが，破断面中に観 察された微小な引張型の破面（ $3 \cdot 3$ 参照）は，このき裂に該当 すると推察される。このダイラタンシーについては次のことがわ かっている（柳谷ら；1987，Hadley；1975， Scholz and Koczynski；1979)。1)垂直な面内の半径方向の伸び量として測 定されるダイラタンシーには方向による差異があり，これが最大 となる方向に破断方位が向く。2)潜在き裂の方位とその破壊に伴っ
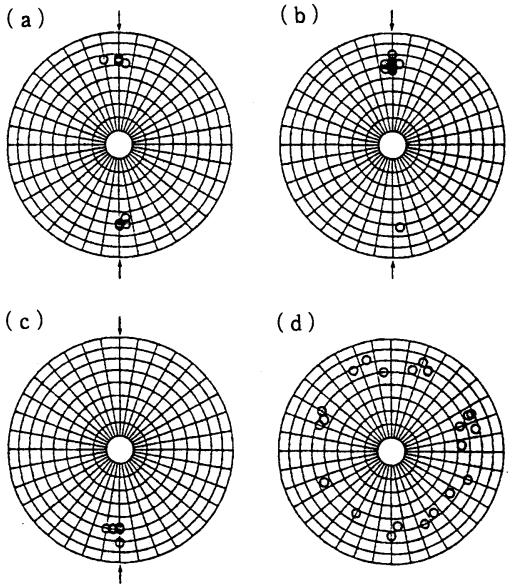

(d)

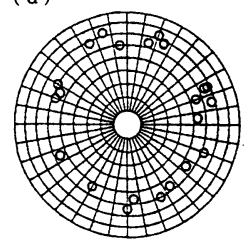

図 11 供試体軸が層理と斜交する場合の破断方位。（a）寒沢砂 岩 $\left(\alpha=30^{\circ}\right)$, (b) 太平洋砂岩 $\left(\alpha=30^{\circ}\right)$, (c) 白浜砂岩 $\left(\alpha=30^{\circ}\right)$, (d) 寒沢砂岩 $\left(\alpha=60^{\circ}\right)$ 。矢印は径方向 $\mathrm{P}$ 波 速度の最も遅い方向を示す。
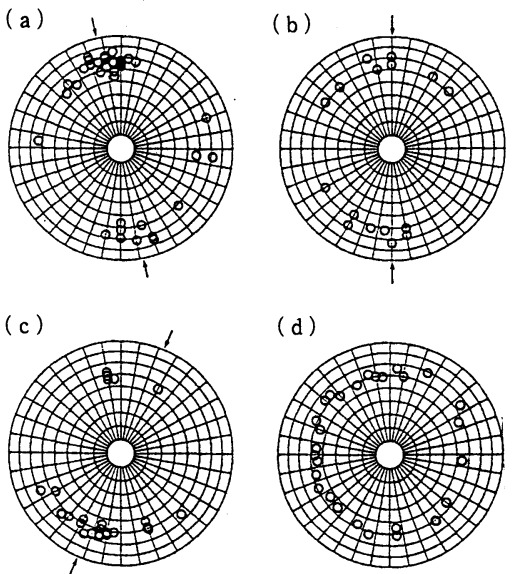

(d)
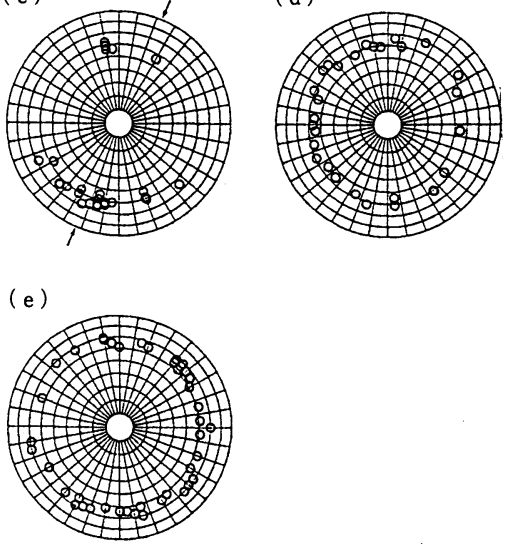

図 12 供試体軸が層理に垂直な場合 $\left(\alpha=90^{\circ}\right)$ の破断方位。 (a)砂川砂岩, (b)美唄砂岩, (c) 寒沢砂岩, (d)太平洋砂 岩, (e)白浜砂岩。矢印は径方向 $\mathrm{P}$ 波速度の最も遅い方 向（L方向）を示す。

て先端から発生する開口き裂の方位は同じであり，これがダイラ タンシーをもたらす。これらの知見から, 方位が最も卓越する潜 在き裂の面と破断面は同一の方位を持つことが予想される。

角度 $\alpha$ が $90^{\circ}$ （供試体軸が層理に垂直）の石狩夾炭層砂岩につ いては, 開口き裂の配向する向きは L 方向に直交しており（第 1 報， 4 - 2 参照)，この向きと卓越する破断方位は一致している。 したがって, 当該供試体に卓越する破断方位が存在し, それが L 方向に一致するのは, 開口き裂の配向性に起因している。この L 方向は，第 1 報で述べたように，開口き裂の配向する向き，およ び供試体の採取地区の地質構造を特徵づける褶曲軸に直交してい る。

このように，砂岩の破断方位および破壊モードは岩石組織の異 方性，ひいては地質作用と深く関わっていると推論できる。 


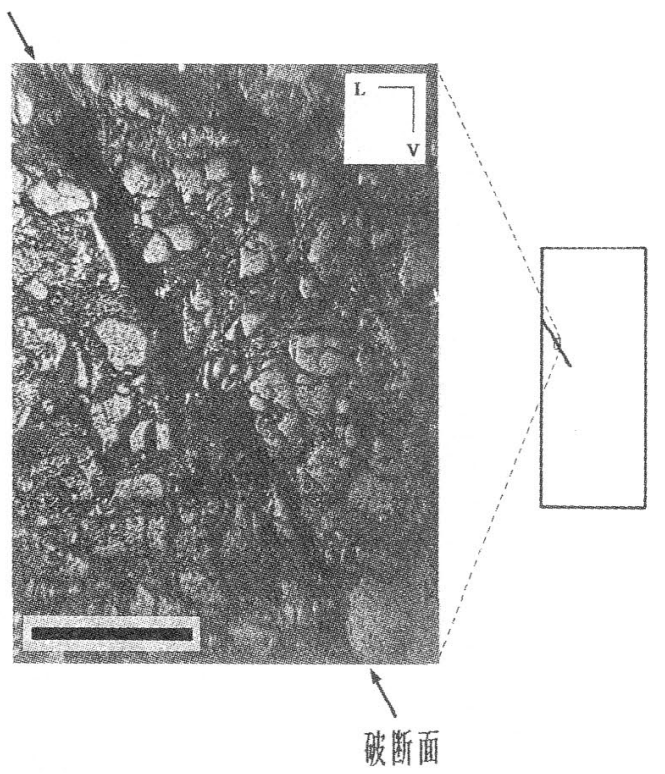

図 13 応力低下過程に扔ける破断面の発達( (赤平砂岩, $\alpha=$ $90^{\circ}$ 、横ひずみ速度制御)。破壊強度点の $95 \%$ の差俯力 レベルで除荷した供試体の観察結果。観察した断面は $\mathrm{H}$ 面に一致する。スケールバーの長さは $0.5 \mathrm{~mm}$ 。

(a)
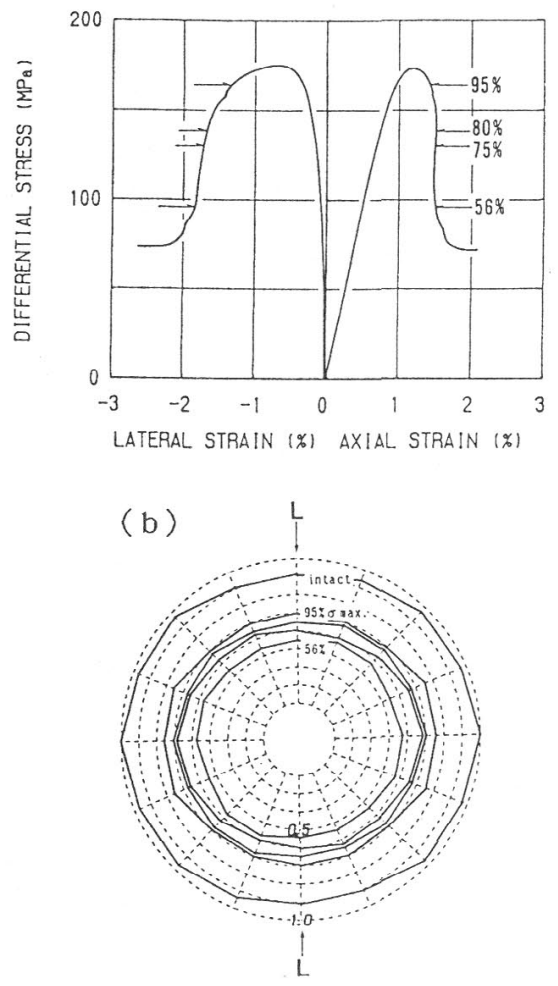

図 14 破壊強度点以降の各差応力レベルでの径方向の $\mathrm{P}$ 波速度 分布 (赤平砂岩, $\alpha=90^{\circ}$ ，横ひずみ速度制御）。(a) 除 荷差応力レベル，(b)速度の減少は, 健硬時の最も速い 径方向の P 波速度の值を 1.0 とした相対的な比率で表す。

\section{4.脆性・延性と供試体の損傷}

$4 \cdot 1$ 脆性における内部構造の変化

図 13 は，軸応力が破壞強度点を越え強度の $95 \%$ になったと きに除荷した供試体（赤平砂岩， $\alpha=90^{\circ}, P_{c}=20 \mathrm{MPa}$ ）につ

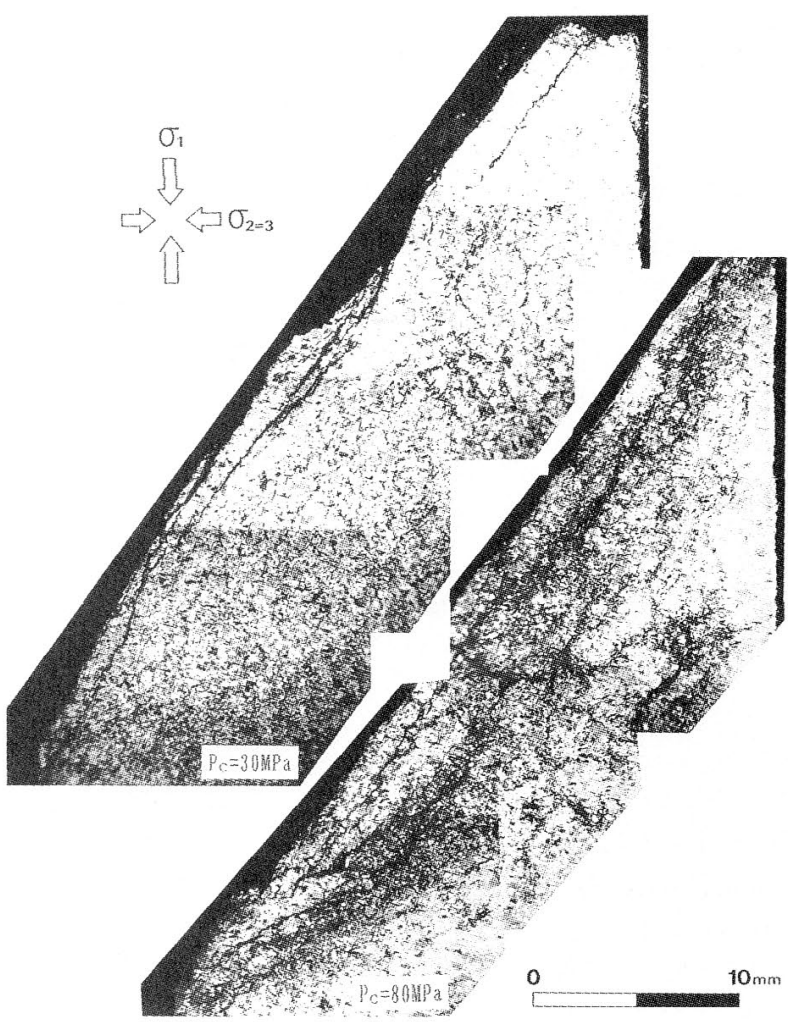

図 15 脆性を示した供試体の破断面近傍の様相（赤平砂岩，a $=90^{\circ}$, 封压 $30 \mathrm{MPa}$ 抢よび $80 \mathrm{MPa}$ )。

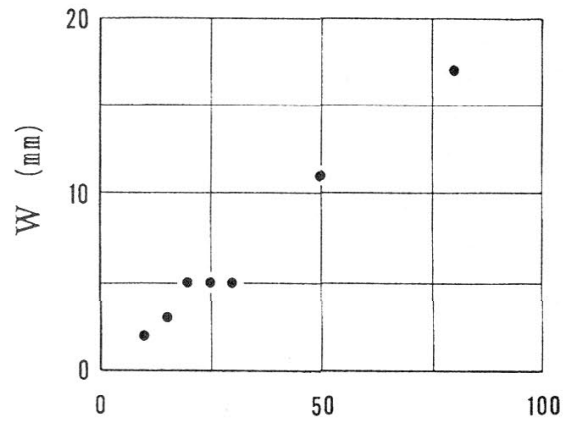

$\mathrm{P}_{\mathrm{c}}(\mathrm{MPa})$

図 16 損傷領域の幅 $W$ と封圧 $P_{C}$ の関係（赤平砂岩， $\alpha=90^{\circ}$ )

いて, 径方向 $\mathrm{P}$ 波速度の最も遅い方向（L方向に一致）と供試 体軸（V 方向）を含む断面（H 面）の顕微鏡写真を示したもの である。長さが径の $30 \%$ 近くに達する破面が供試体内部に発生 しているが，この破面は供試体を買通する破断面に成長する過程 にあったと考えられる。この例が示すように，応力が破壊強度点 を越えるとまもなく破断面の形成が始まるようである。破断角の 実測值は破壊強度の限界線に基づく理論的な角度とよく一致する が ( 3 . 3 参照), これも破壊強度点を過ざた直後に破断面の位 置が決定するという証左を与えている。

次に，破壊の進行が径方向 $\mathrm{P}$ 波速度に及ぼす影響を調べるた めに，4個の供試体を封圧 $20 \mathrm{MPa}$ の下での圧縮試験に供し，図 14(a)に示すように，破壊後の応力低下過程に扔ける4つの異な る差応力レベルで除荷した。除荷後に測定した P 波速度は, 図 （b）に示すように，破壊の進行とともに減少している。しかし， 速度分布の形状は保たれており，楕円で近似されるダイヤグラム の長軸あるいは短軸の方向は, 破壊の前後で変わっていない。こ 
(a)
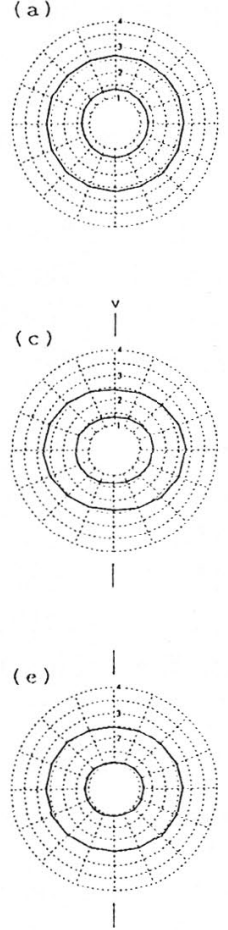

(b)
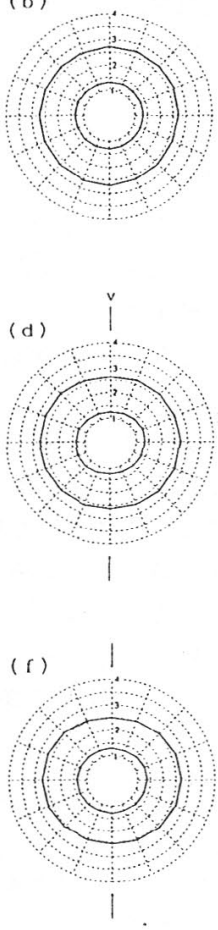

図 17 延性を示した供試体の健硬時（外側）抢よび載荷終了後 (内側) の径方向 $\mathrm{P}$ 波速度分布（太平洋砂岩, 封圧 70 $\mathrm{MPa}$ ，軸ひずみ速度制御）。図中の数值は $\mathrm{P}$ 波速度（km

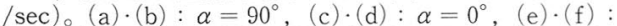
$\alpha=30^{\circ}$ 。矢印は径方向 $\mathrm{P}$ 波速度の最も遅い方向を示方。

のように, 組織の異方性は破断面が発達しつつある応力低下過程 でも保持される。

今度は, 破断面近傍の微視的構造の変化について述べる。応力 が残留強度点に達した後に除荷した供試体を用い, 切り出した供 試体軸を含む所定の断面に青色のエポキシ樹脂を含浸させた後， 鏡下で観察した。図 15 は供試体軸を含み破断面に垂直な断面の

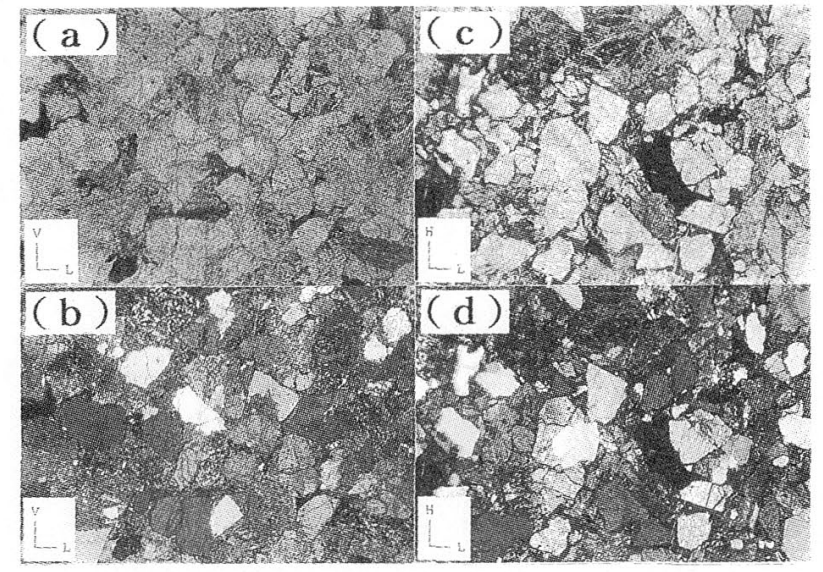

図 18 延性を示した供試体の内部構造（太平洋砂岩， $\alpha=90^{\circ}$, 封圧 $70 \mathrm{MPa}$ )。(a)層理に垂直な断面・平行ニコル，(b) 同・直交ニコル, (c) 層理に平行な断面·平行ニコル, (d) 同・直交二コル。

一例で，破断面に沿って青色樹脂，つまり，き裂が密に分布した 带状の領域が認められる。図 16 は, このようなき裂が発達した 損傷領域の幅 $W$ と封圧の関係を示したもので, 損傷領域の幅 $W$ は封圧の増大とともに増加していることがわかる。

\section{$4 \cdot 2$ 延性における内部構造の変化}

延性を示した太平洋砂岩について，軸ひずみが $5 \%$ に達した 後, 除荷し P 波速度を計測した。その結果を示した図 17 から， 試験後の P 波速度は載荷前の 40５％％の大きさに留まっており， 速度が著しく減少することがわかる。なお， $\alpha=90^{\circ}$ の場合， ダ イヤグラムは楕円形となり, 最大 $5 \%$ 程度の速度差が現れてい るが，この棈円の長短軸の方位は供試体ごとに異なっており，特

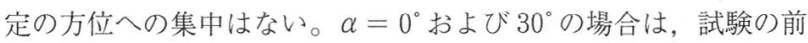
後でダイヤグラムの長短軸の方位が変わらず，また，試験前と同 様，10\% 程度の速度差がある。
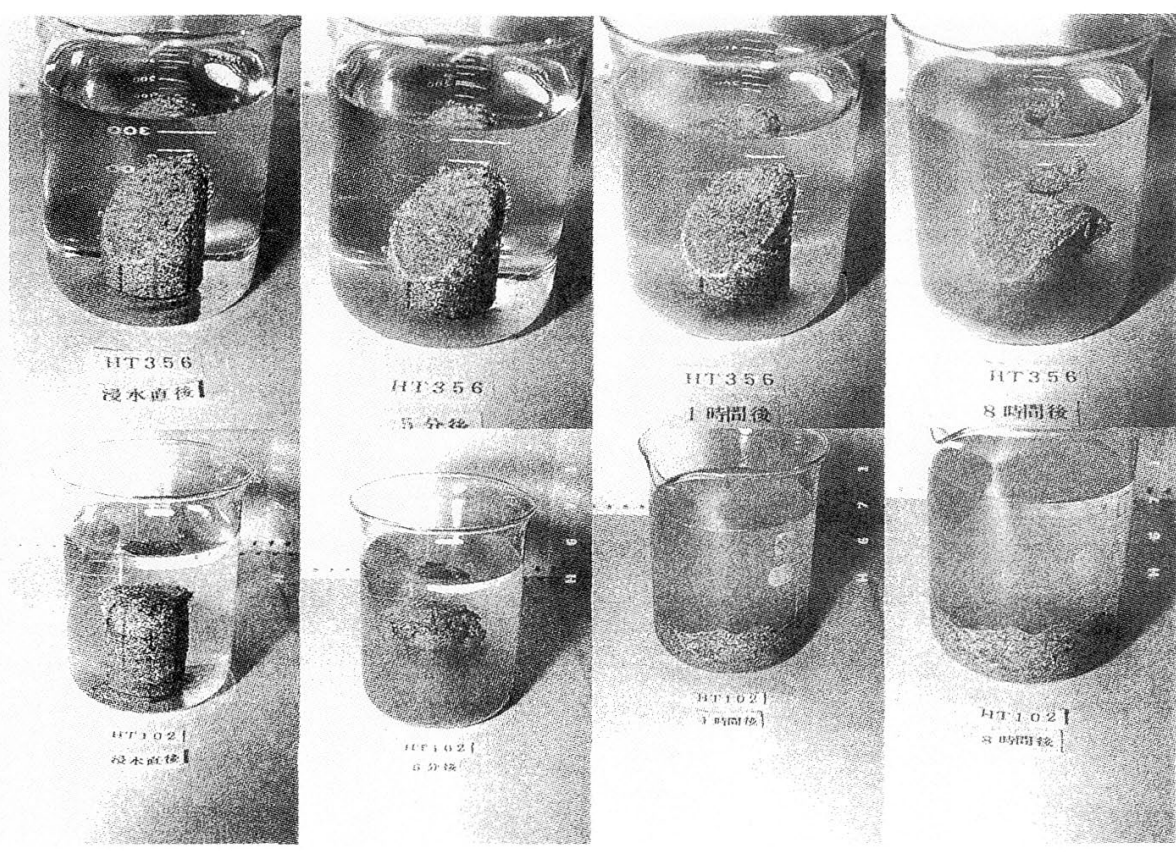

図 19 浸水崩壊度試験結果（太平洋砂岩, 上段：封圧 $30 \mathrm{MPa}$, 下段：封圧 $70 \mathrm{MPa}$ )。 
$3 \cdot 4$ で述べたように, 延性の場合には巨視的な破断面は形成 されず, 脆性の場合に破断面近傍に発生するのと同様の損傷領域 が供試体の内部全体に広がる(Bernabe and Brace, 1990)。図 18 は延性を示した $\alpha=90^{\circ}$ の太平洋砂岩の観察結果である。供試 体軸に平行な断面内では, 図(a), (b)のように, 供試体軸方向に 伸長するき裂が特に石英粒子内で多く見られる。供試体軸に垂直 な断面内では, 図(c)(d)のように, 粒子内のき裂の発生や粒界の 著しい損傷が認められるが, 粒子の回転や再配列は起きていない。

\section{$4 \cdot 3$ 試験後の供試体の浸水崩壊度}

供試体の損傷状態は, 浸水崩壊度試験結果からも伺うことがで きる。太平洋砂岩の無負荷試料の浸水崩壊度（土質工学会, 1974）はA ランクに属し，8時間浸水させても全く変化しない。 ところが, 封圧 $30 \mathrm{MPa}$ の下で単一のせん断面の形成を伴って脆 性破壊した供試体を浸水試験に供したところ, 破断面の近傍だけ が徐々に変化し, 綿状を呈した。これは, 図 15 に示したような き裂の密集した損傷領域が吸水・膨張したことを示唆している (図 19 上段参照)。

封圧 $74 \mathrm{MPa}$ の下で延性を示し軸ひずみが $10 \%$ になったとき に除荷した供試体の場合, 浸水直後から供試体全体が急激に膨張 し，1時間後には完全に崩壊し粉状化した（図 19 下段参照）。 前節で述べたように, 延性の供試体は, 外観上自立しているも のの, $\mathrm{P}$ 波速度は載荷前の半分になっており凝集力が完全に消滅 し, いわゆる砕首性流動を起こしている。激しい浸水崩壊現象は この推測が妥当であることを示している。

\section{5. 結}

本研究では, 石狩夾炭層砂岩を中心とする砂岩供試体を用いて 封圧下の圧縮試験を行い, 変形・強度特性, 破壊の様相などに関 する実験結果をまとめた。得られた主な知見を箇条書きに示す。

1. 最大圧縮応力一最小圧縮応力座標において, 破壊強度の限 界線は傾きの異なる 2 直線で近似でき, 限界線の傾きから予想さ れる破断角は実測值とよく合う。
2. 破壊限界線の 2 直線の交点の封圧を境に，封圧がこれより 大きいか小さいかによって, 体積ひずみ挙動, 破断角の増加率, 破断面の性状が異なっている。

3. 破壊強度ならびに残留強度は, 組織の異方性に影響されず ほぼ等方的である。

4. 径方向の $\mathrm{P}$ 波速度の分布が異方性を示すときには，脆性 破壊時に生じる破断面の向きは速度の最も遅い方向に集中し, 単 一せん断型の破壊モードが卓越する。等方性を示すときには, 破 断面は特定の方向に集中せず, 交差せん断型の破壊モードが卓越 する。

5.4.の結果は, 破断面の方位と破壊モードが岩石組織の異 方性ひいては地質作用の影響を強く受けることを示している。

6. 応力状態が破壊強度点を越える前後から破断面の形成が始 まる。脆性破壊時に現れる破断面の周りには, この面に平行なあ る幅の凝集力のない損傷域が形成される。この幅は封圧とともに 増大し, 延性時には供試体全体を覆い, 砕屑性流動が生じる。

\section{引用 文 献}

Bernabe Y. and Brace W. F. (1990) : Geophys. Mono. 56, Am. Geophys. Union, Washington D. C., p. 91-101

Donath F. A., Faill R. T. and Tobin D. G. (1971) : Bull. Geol. Soc. Am., Vol. 82 , p. $1441-1461$

土質工学会編 (1974）：岩の工学的性質と設計・施工への応用, p. 106, 土質工学会 Griggs D. T. and Handin J. (1960) : Geol. Soc. Am., Memoir, Vol. 79, p. $347-364$

Hadley K. (1975) : J. Geophys. Res,, Vol, 80, p. 4845-4850

萩野克彦·中村 章·石島洋二 $(1996 \mathrm{a})$ ：資源と素材，p. 601-608

萩野克彦·中村 章·石島洋二 $(1996 \mathrm{~b})$ : 資源と素材, 投稿中

茂木清夫 (1974)：固体の流動（上田誠也編）, 東海大学出版会, p. 96-108

中村 章 (1978)：北海道大学学位論文

中村 章·石島洋二 (1987) : 北海道大学工学部研究報告, Vol. 137, p. 1-17

中村 章·石島洋二 (1988) : 北海道大学工学部研究報告, Vol, 140, p. 51-62

Scholz C. H. and Koczynski T. A. (1979) : J. Geophys. Res., Vol. 84, p. $5525-5534$

柳谷 俊·西山 哲·寺田 孚 $(1987)$ ：土木学会論文集，Vol, 382/III-7, p. 63-72 